\title{
Acontecimento e narrativas midiáticas: elos entre a tragédia do Maracanaço e o vexame da Copa do Mundo de 2014
}

\section{Event and media narratives: links between the tragedy of Maracanaço and disgrace of 2014 World Cup}

\author{
Magnos Cassiano Casagrande | Universidade Federal de Santa Maria \\ Doutorando em Comunicação no Programa de Pós-Graduação \\ em Comunicação da Universidade Federal de Santa Maria \\ E-mail: magnoscassiano@yahoo.com.br
}

Ada Cristina Machado Silveira | Universidade Federal de Santa Maria Professor Associado IV da Universidade Federal de Santa Maria. Professora do Programa de PósGraduação em Comunicação da Universidade Federal de Santa Maria. Doctorado en Periodismo - Universitat Autònoma de Barcelona (2000) e com estágio pós-doutoral na Sorbonne III - La Nouvelle (França) e na Universidad Nacional de Quilmes (Argentina) E-mail: adac.machadosilveira@gmail.com

\begin{abstract}
Resumo
O presente texto discute, em âmbito teórico, a relação entre acontecimento e narrativa midiática. Através de Louis Quéré, situa-se o acontecimento na dialética da experiência, originária da interação entre sujeitos e acontecimentos. Pensa-se a narrativa como um lugar de manifestação e representação das culturas e das açóes dos sujeitos sobre o mundo. Volta-se para a narrativa por meio da tríplice mimese de Paul Ricoeur. No âmbito analítico, o texto realiza incursóes e interpretaçôes acerca da derrota da seleção brasileira de futebol para a seleção alemã por sete gols a um na semifinal da Copa do Mundo de Futebol de 2014 e busca compreender como as capas de alguns jornais brasileiros produzem uma ressignificação do revés do Brasil na Copa de 1950, conhecido como Maracanaço.
\end{abstract}

Palavras-Chave: Acontecimento; Narrativas midiáticas; Copa do Mundo.

\begin{abstract}
The present text discusses in theoretical scope the relationship between event and media narrative. Through Louis Quéré, lies the event in the dialectic of experience, originating from the interaction between subjects and events. One thinks the narrative as a place of manifestation and representation of cultures and actions of the subjects on the world. Turns to the narrative through triple mimesis of Paul Ricoeur. In the analytical scope, the text carries out incursions and interpretations about the defeat of the Brazilian national soccer team to the German team for seven goals to one in the semifinal of the 2014 World Cup Soccer and seeks to understand how the cover pages of some Brazilian newspapers produce a reframing Brazil's setback in the 1950 World Cup, known as the Maracanaço.
\end{abstract}

Keywords: Event; Media Narratives; World Cup 
O presente texto aborda, em linhas gerais, o conceito de acontecimento em sua natureza existencial e experiencial na visada de Louis Quéré, assim como a narrativa dos acontecimentos, a mise em intrigue midiática, a partir de Paul Ricoeur. Ao longo do percurso, direciona-se o olhar para a derrota da seleção brasileira de futebol na Copa do Mundo de 2014 para a seleção alemã pelo placar de sete (7) gols a um (1) e para as relaçóes estabelecidas por algumas capas de jornais publicadas no dia seguinte ao revés com outro resultado histórico, a derrota por dois (2) gols a um (1) sofrida diante Uruguai na final da Copa de 1950, conhecida como Maracanaço.

Qualquer acontecimento interconecta uma série de fatos que estavam dados, mas que, geralmente, ganham visibilidade após a irrupção do inesperado, ou seja, com algo que rompe com a ordem natural e cotidiana. Antes disso, é possível que os fatos sejam pouco lembrados e a busca de significado para eles seja limitada. Caso conectados, podem ser responsáveis pela ocorrência do imprevisível ou daquilo que não se projetava como possível. $\mathrm{O}$ acontecimento que ganha maior relevância é aquele que se encaixa na ordem do inesperado, da surpresa e, consequentemente, ganha importância e sobressai-se, ao menos midiaticamente, em relação aos demais. A eliminação da seleçáo mais consagrada de futebol em uma Copa do Mundo, por si só, é de grande relevância para o discurso jornalístico. A derrota por sete gols a um, resultado inédito nas semifinais do torneio e para a seleção brasileira, caracterizada pelo drama/fracasso/melancolia de um lado e pelo sucesso de outro potencializa o já intrínseco poder hermenêutico e de revelação do acontecimento.

A derrota de 2014 não é o primeiro acontecimento do ramo futebolístico nacional taxado como tragédia, vexame ou vergonha. Em 1950, o Brasil sediou a Copa do Mundo de Futebol, chegou à final da competição disputada no Estádio Mário Filho, Maracanã e, amplamente favorito, acabou derrotado por dois gols a um pela seleção do Uruguai. O Maracanaço representava a pior derrota da seleção até a ocorrência do 7x1. Desse modo, objetiva-se, na parte analítica do texto, verificar como 1950 reaparece nas capas dos jornais após a derrota de 2014, ou seja, como é refigurado e quais as novas configuraçóes que recebe.

Tem-se claramente a articulação entre dois acontecimentos concretos ligados em um tempo histórico por suas características semelhantes e pelo investimento realizado pelas narrativas da mídia esportiva. Tudo isso faz com que novos sentidos surjam tanto para o acontecimento mais passado quanto para o mais recente. Pretende-se identificar fragmentos dessa intriga que se manifestam nas capas de jornais impressos. Fragmentos que podem ser chamados de elementos atualizadores das narrativas que permitem pensar na mídia esportiva como um agente de atualizaçáo dos acontecimentos. Com efeito, tenta-se mostrar a apropriação do novo acontecimento e a elaboraçáo de novas interpretaçóes para acontecimentos passados. 


\section{Acontecimento, experiência e o $7 \times 1$}

O papel das narrativas, principalmente das narrativas midiáticas, consiste na exploração, configuração, busca de causas e consequências e na instauraçáo de um processo cognitivo e discursivo acerca do acontecimento que, conforme Quéré (2005), passarão pelo julgamento do público.

Elenca-se uma série de fatores, sem a pretensão de ser exaustivo, que estão conectados ao $7 \mathrm{x} 1$, resultado de sete (7) gols para a Alemanha e um (1) gol para o Brasil, na semifinal da Copa do Mundo de Futebol de 2014: a representatividade da seleção brasileira, maior campeã da competição (cinco títulos) e a responsabilidade por vestir sua camisa; a responsabilidade por ser o país sede e ter na memória a derrota na final da Copa de 1950, incessantemente retomada pelas narrativas da mídia esportiva e viva no imaginário futebolístico nacional; a seleção alemã era mais equilibrada tática e emocionalmente e atuou com uma equipe que começou a ser formada há cerca de dez anos, fato preponderante para o sucesso, pois além de derrotar o Brasil, sagrou-se campeã ao vencer a Argentina na final pelo placar de um gol a zero; a seleção brasileira não vinha apresentando um futebol de boa qualidade ao longo do torneio. Além disso, o acontecimento $7 \mathrm{x} 1$ faz reverberar, ao menos na cobertura midiática, a estrutura do futebol brasileiro, as ações e imbróglios da Confederação Brasileira de Futebol (CBF), a qualidade do futebol nacional e a participação majoritária de jogadores que atuam no futebol de outros países, especialmente europeus, em virtude da globalização do mercado futebolístico, fato que provoca certo rompimento de relaçóes com a formação do atleta.

Pode-se dizer que todos os fatores aqui elencados tornam-se "problemas conexos" ao acontecimento 7x1 e, muitos deles, passam a ser relevantes após a manifestaçáo do inesperado. Os apontamentos se justificam por ajudarem na compreensão dos acontecimentos, bem como para situá-los em relação aos demais. Trata-se da tarefa de explorar "o potencial de inteligibilidade e de discriminação dos acontecimentos” (QUÉRÉ, 2005, p.72).

Afirma-se, através de Quéré (2005, p.61), que o 7x1 “introduz uma descontinuidade", em virtude de ser inesperado, de exceder os prognósticos possíveis para a partida, ser inédito e diferenciar-se drasticamente da continuidade, ou seja, dos resultados já ocorridos nas semifinais da competição e com a seleçáo brasileira ao longo da história. Tem-se certo rompimento com o passado e o foco volta-se para as consequências do acontecimento. $\mathrm{O}$ novo domina os demais e o ser humano busca, como diz o autor, olhando para o passado, restaurar a continuidade, que passa a ser pensada após a manifestação e a ocorrência do inesperado.

Sempre existem condiçóes que possibilitam o acontecimento e este, sendo descontínuo, as excede. Pensamos que o autor está querendo afirmar o caráter imprevisível de alguns acontecimentos, que só depois de acontecerem é que se dão a ver em suas "possibilidades, potencialidades e eventualidades" (QUÉRÉ, 2005, p.63). Charaudeau (2006) pensa a imprevisibilidade como condição inerente do acontecimento. Desse modo, ela é um elemento constitutivo das partidas de futebol, em que nem sempre a melhor equipe vence ou 
consegue alcançar o êxito, em que um pequeno detalhe é capaz de mudar a história do jogo. Mesmo que os torcedores, os jornalistas e os analistas traçam prognósticos antes e durante as partidas, tentando reduzir o grau de imprevisibilidade, jamais conseguem fazê-lo na totalidade.

Projetando sentidos e reconfigurando "as possibilidades, para sujeitos dotados de uma certa sensibilidade e de hábitos" é que os acontecimentos, segundo Quéré (2005, p.70), "se inscrevem na ordem dos sentidos". A partir dessa transação é que se tem a experiência. A experiência é constitutiva dos sujeitos e dos mundos do sujeito e dá-se no agenciamento destes com os acontecimentos, que fazem fruir uma "articulação estreita entre o suportar e o agir”. O conhecimento e ação do sujeito sobre um acontecimento é uma parte essencial da compreensáo tanto do acontecimento quanto do sujeito. A experiência "é fonte de identidade, ao mesmo tempo para o acontecimento e para quem, por ele, é atingido”, escreve Quéré (2005, p. 70). Com efeito, a experiência e os acontecimentos constituem a identidade dos sujeitos, assim como a apropriação destes dá significado e possibilita que o acontecimento adquira uma identidade. A apreensão e configuração do $7 \mathrm{x} 1$ passa por esse processo de experiências que liga o acontecimento aos sujeitos que, de alguma forma, foram afetados, ou estiveram nele envolvidos ou por ele se interessaram.

Quéré (2005, p.60) situa o acontecimento na "dialéctica da experiência”, que diz respeito ao potencial de afetação dos sujeitos e a consequente atitude responsiva, à "articulação estreita entre o suportar e o agir”. Segundo o autor, é isso que possibilita George Mead pensar o acontecimento como "o que vem a ser" e possibilita a conversão de “acontecimentos existenciais em acontecimentos-objetos" (2005, p. 24). A conversão em que os acontecimentos-objetos são "objetos de consciência, de pensamento, de discurso, de investigação e de julgamento" dá-se numa atitude de intervençâo "no curso dos acontecimentos, a atenuar seu impacto, a domesticá-los um pouco”. Pensa-se que os acontecimentos são tomados dessa forma pelos meios de comunicação, eis o ponto de intersecção daqueles com a narrativa midiática. Os acontecimentos transformam-se em objetos dotados de significação, invade-se seu passado, projeta-se um futuro a partir dele, investigam-se suas causas, debruça-se sobre suas consequências, tenta-se apreender o que o acontecimento suscita em termos de sentido. Chega-se a um objeto cognitivo e discursivo, importante para o entendimento da relação entre acontecimento e narrativa. Segundo Quéré (2005), a conversão não isola o acontecimento, pelo contrário, coloca-o em relação com os demais. Além disso, sua compreensão e relevância dependem das circunstâncias em que é observado, por quem é observado e por quem é experienciado.

A ideia de acontecimento-objeto é compreendida por Quéré, inspirando-se em John Dewey, com uma "segunda vida do acontecimento". Desloca-se o acontecimento através do pensamento acerca dele, ao mesmo tempo em que o acontecimento-objeto através da experimentação e do processo de significação pode "entrar em interaçáo com os acontecimentos em estado bruto e não tratados” (QUÉRÉ, 2012, p. 31). Com 
efeito, a segunda vida do acontecimento refere-se à colocação do acontecimento em um determinado curso ou para intervir no curso deste: "servimo-nos deste tipo de objeto cognitivo-discursivo para intervir no curso dos acontecimentos, a fim de canalizá-lo ou atenuar sua brutalidade. Os acontecimentos-objetos tornam-se, assim, agentes da história que se faz”, afirma Quéré (2012, p. 31).

O sujeito humano ao deter-se a um acontecimento investe, portanto, sobre algo que irrompe no presente. Apesar do acontecimento ser passado e irrecuperável é possível apreendê-lo, questioná-lo, compreendê-lo, principalmente, através de narrativas sobre ele e através de narrativas que ele comporta. São as características de embate, uma espécie de diálogo inconcluso, que guiam a configuração narrativa de um acontecimento. Cabe ao sujeito entender que perguntas o acontecimento suscita. Sabe-se que as explicaçôes não conseguem ser exaustivas nem apreender a totalidade de uma situação. Com efeito, a narrativa partirá sempre de um ponto de vista do acontecimento.

\section{Acontecimento e narrativa midiática}

Sabe-se da importância e da potencialidade da narrativa midiática diante dos acontecimentos, de seu potencial de abrir, fechar ou obstruir caminhos no processo de compreensão daqueles. De modo semelhante a Quéré, França (2012, p. 46) afirma que para alcançar uma maior apreensão dos sentidos do acontecimento, é preciso "tomá-lo como ocorrência desencadeadora de sentidos" e considerar seu potencial de revelação e "seu poder hermenêutico". Ambos autores afirmam que os meios de comunicação não são os lugares em que se dão os acontecimentos, mas onde estes são configurados. Tal processo de configuração dos acontecimentos através de narrativas midiáticas é que interessa para pensar a interação entre as derrotas da seleção brasileira de futebol nas Copas de 1950 e 2014.

Concorda-se, com efeito, com o que Carvalho e Lage (2012, p. 221) asseveram:

O que é preciso reconhecer é o indispensável papel da mediação narrativa para a configuração - e não constituição, no sentido existencial - dos acontecimentos, o que, por sua vez, implica a articulação de diferentes agentes sociais que entram como personagens da estória do acontecimento, mas também o conhecimento que temos do mundo da ação, o modo como tal acontecimento é configurado pelas diversas narrativas midiáticas e, principalmente, a maneira como é refigurado, isto é, como é interpretado. Eis, a nosso ver, a associação possivel e necessária das visadas hermenêutica e pragmatista. (CARVALHO e LAGE. 2012, p. 221)

Os autores destacam que as mídias proporcionam "modos distintos de experiência” acerca dos acontecimentos, sendo que grande parte dos acontecimentos chegam ao público via instâncias midiáticas. Acontecimentos como grandes eventos esportivos já nascem midiatizados, sendo comunicado a milhôes de pessoas em tempo real. Tem-se, com efeito, o acontecimento e a imediata construção de sentido acerca dele e a posterior tentativa de compreensão. 
A articulação entre mídia e acontecimento promove, nas dimensóes citadas, o desenvolvimento da capacidade de revelação e das "potencialidades heurísticas do acontecimento”. Começa-se a pensar essa interconexão através dos três tempos miméticos desenvolvidos por Paul Ricoeur: mimese I, mimese II e mimese III.

A mimese I refere-se a uma prefiguração ou preconfiguração do mundo. Para Ricoeur (1994, p.101), mimese I faz referência as dimensóes estruturais (semânticas), simbólicas e temporais em torno das quais o mundo se organiza e seu sentido está em "imitar ou representar a ação, é primeiro, pré-compreender o que ocorre com o agir humano: com sua semântica, com sua simbólica, com sua temporalidade”. As três dimensões já estão dadas de antemão a qualquer acontecimento e são resumidas da seguinte forma por Carvalho (2012, p.175):

A primeira diz respeito, imediatamente, às próprias formas narrativas mais caras a uma determinada sociedade [...]. A segunda dá conta de um conjunto de mitos, crenças, valores, questôes éticas e morais, enfim, a uma ampla gama de manifestaçóes típicas da cultura, enquanto a última é articuladora de sentidos ao remeter às diversas possibilidades de que a temporalidade, cronológica ou de outra natureza, é portadora. (CARVALHO, 2012, p.175)

Destaca-se que os acontecimentos originam-se em meio a essa prefiguração e já nascem com o potencial de serem narrados: "Se, com efeito, a ação pode ser narrada, é porque ela já está articulada em signos, regras, normas: é desde sempre, simbolicamente mediatizada." RICOEUR, 1994, p.91, grifo do autor) A articulação e configuração cabe à narrativa. Os acontecimentos do mundo, em sua natureza existencial, são percebidos e experienciados pelos sujeitos. O conceito de experiência volta a ser importante para o texto pois, como afirma Charaudeau (2006, p.97), o primeiro tempo mimético depende "de uma relação experiencial direta e global entre o sujeito e o mundo". A relação experiencial é condicionada pelas três dimensôes apresentadas, pois são elas as bases que antecedem o ato de configuração do mundo pré-figurado. Eis a razão de Ricoeur, segundo Carvalho (2012), fazer referência à necessidade de um compromisso ético, pois ele é a base da narrativa que será configurada na sequência, pelos sujeitos.

$\mathrm{O}$ ato/gesto de configuração do mundo pré-figurado constitui o segundo tempo mimético para Ricoeur (1994). A mimese II refere-se a certo ordenamento de sentidos, ao agenciamento de situaçóes, sujeitos, qualificaçôes, ou seja, a um ato de configuração do mundo. Com efeito, mimese II "constitui o pivô da análise" caracterizando-se por "sua função de mediação", mediação entre o mundo prefigurado e refigurado, entre a pré-compreensão e o ato de leitura e interpretação do sujeito leitor, mediação entre mimese I e mimese III, e estabelece um virtuoso "círculo hermenêutico” (RICOEUR, 1994, p. 86). O ato de configuração é a tessitura da intriga, sendo a intriga a mediação entre o que antecede e sucede a narrativa. Ricoeur (1994, p.103-104, grifos do autor) apresenta alguns motivos que tornam a intriga uma instância mediadora: "faz 
mediação entre acontecimentos ou incidentes individuais e uma história considerada como um todo [...]; transforma os acontecimentos ou incidentes em - uma história", ou seja, "extrai de uma simples sucessão uma configuração", classificada pelo autor como uma "sintese do heterogêneo", fazendo referência tanto aos fatores quanto "a agentes, meios, interaçôes, circunstâncias, resultados inesperados, etc”. A função de mediação exercida pela mimese II aproxima-se da ideia de acontecimento-objeto apresentada anteriormente. Ambos baseiam-se em algo anterior e buscam elaborar uma compreensão acerca das situaçôes do mundo.

O círculo hermenêutico completa-se, segundo Ricoeur (1994, p.110-118, grifos do autor), com a integração do leitor da narrativa na trama, o qual é um agente ativo e reconfigura o mundo configurado: "a narrativa tem seu sentido pleno quando é restituída ao tempo do agir e do padecer em mimese III". A ação do leitor representa para o autor um ponto de chegada: "é bem no ouvinte ou no leitor que se conclui o percurso da mimese". Com efeito, refuta completamente a passividade do leitor e coloca-o como essencial, sem ele e sem a produçáo de sentidos que ali ocorre o restante passa a impressão de ser algo desfigurado e sem orientação, pois o que orienta mimese II é o ideal de chegar ao receptor da narrativa: "mimese III marca a intersecção entre o mundo do texto e o mundo do ouvinte ou do leitor [...] É no ato de ler que o destinatário joga com as coerçóes narrativas, efetua os desvios [...] e tem o prazer que Roland Barthes chamava de prazer do texto". Trata-se de um processo de compreensão e interpretação que possui um viés de resposta, em que o sujeito, segundo Charaudeau (2006, p.97), reconstrói "uma significação, em função de sua própria finalidade de ação e de sua própria experiência intelectiva e afetiva, a partir do mundo construído pelo outro". Um processo dialógico e de movimento tanto do leitor quanto da narrativa, ou seja, um processo de refiguração tanto da narrativa quanto da interpretaçáo acerca dos acontecimentos do mundo. Dito isso, concorda-se com Resende (2009) quando afirma que é na tessitura da intriga que estão as possibilidades de encontro entre os sujeitos.

Conforme Carvalho (2012, p.174-181), mimese para Ricoeur não se refere à "imitação da vida", é, na verdade, "a colocação em ação das relaçôes entre tempo e tessitura da intriga, sendo nesse processo que a vida [...] envolvendo sujeitos, ganha sentido". O autor propóe que o pensamento desenvolvido pelo filósofo francês acerca da tríplice mimese e seu viés hermenêutico, que possibilita uma compreensão dos acontecimentos do mundo, assim como da "construção da narrativa" e de suas mediações, é "aplicável às narrativas jornalísticas em seu haver com o mundo social”. Assim como a narrativa em Ricoeur, a narrativa midiática desperta sentidos a partir da intervenção dos outros sujeitos.

$\mathrm{O}$ ato de narrar, em si próprio, é um ato constituinte e nobre da experiência humana que atende, a um fim, alcançar o outro sujeito da relação, o destinatário, isto é, fazer viver a comunicabilidade. (LEAL, 2013, p. 53) Com efeito, é um meio de proposição de "organização do mundo", assim como de relaçáo entre os sujeitos e destes com o mundo. A experiência da e através da narrativa relaciona-se à vivência, ao devir humano, à constituição dos sujeitos. A narrativa é a maneira, através 
da qual o ser humano tentar compreender os fatos do mundo e "de dar sentido à vida". Através dela, o sujeito encadeia "acontecimentos, qualidades, traços, momentos e afetos", constitui-se e encontra uma forma de experimentação do mundo.

A narrativa consiste na articulação de acontecimentos, surge pra contá-los e mantê-los vivos no tempo. Desse modo, "toda narrativa é um agir em relação aos acontecimentos, ou seja, envolve um esforço para sua apreensão, no qual a linguagem também é acionada", mesmo sabendo-se da impossibilidade de apreender os acontecimentos do mundo em sua totalidade (LEAL, 2013, p. 34-35). De acordo com o autor, Ricoeur pensa a narrativa como "um modo de saber", uma forma de "possibilitar a experiência do mundo", ou seja, a narrativa é "uma atividade, que se dá na linguagem e adquire, então, a forma de texto, que, por sua vez é prenhe de mediaçóes, é parte dos processos de saber e de experiências que a particularizam como um fenômeno relacional dinâmico e complexo". Como mencionamos, o modo de ação do sujeito no mundo é um processo dinâmico, pensado por Ricoeur (1994) através de um processo mimético (tríplice mimese). Assim, insere-se a narrativa midiática em uma relação comunicacional que envolve a reciprocidade dos sujeitos e na qual considera-se a importância da ação do destinatário/ receptor - a refiguração sugerida pela mimese III.

Segundo Resende (2009, p. 32), o processo mimético, na tessitura da intriga de uma narrativa, promove a relação entre três mundos: o "do autor, o do texto e o do leitor". O sujeito, ao narrar, entra em um processo de apreensão do mundo, de si mesmo e do outro. A partir disso, nos envolvemos e passamos a fazer parte das histórias que nos são contadas e que por nós também são refiguradas. A narrativa midiática incorpora e possibilita mediaçóes, representaçóes socioculturais e manifestação de valores e diz respeito a relaçóes entre sujeitos. Fatores que, num viés hermenêutico, são fundamentais para a compreensão dos acontecimentos e dos fatos do mundo

\section{Maracanaço: refiguração e novas configurações}

Servimo-nos da configuração, especialmente midiática na contemporaneidade, para manter os acontecimentos vivos e dotados de certa importância na sociedade e no imaginário cultural. Como descrito anteriormente, toda configuração abre espaço para a refiguração, ou seja, para um processo de leitura. A derrota da seleção brasileira para a seleção uruguaia por dois (2) a um (1), chamada popularmente de Maracanaço, que culminou na perda do título da Copa do Mundo de 1950 realizada no Brasil, é um exemplo de acontecimento que fica pulsando constantemente no imaginário dos torcedores e através de narrativas construídas que o exploram como um produto cultural e simbólico.

Os meios de comunicação retomam o acontecimento e a narrativa da Copa de 1950 após a derrota de 7x1 na Copa de 2014. Com efeito, lançam outros sentidos para aquele acontecimento como é possível verificar em três capas de jornais publicados no dia nove de julho de 2014, dia posterior à derrota. 

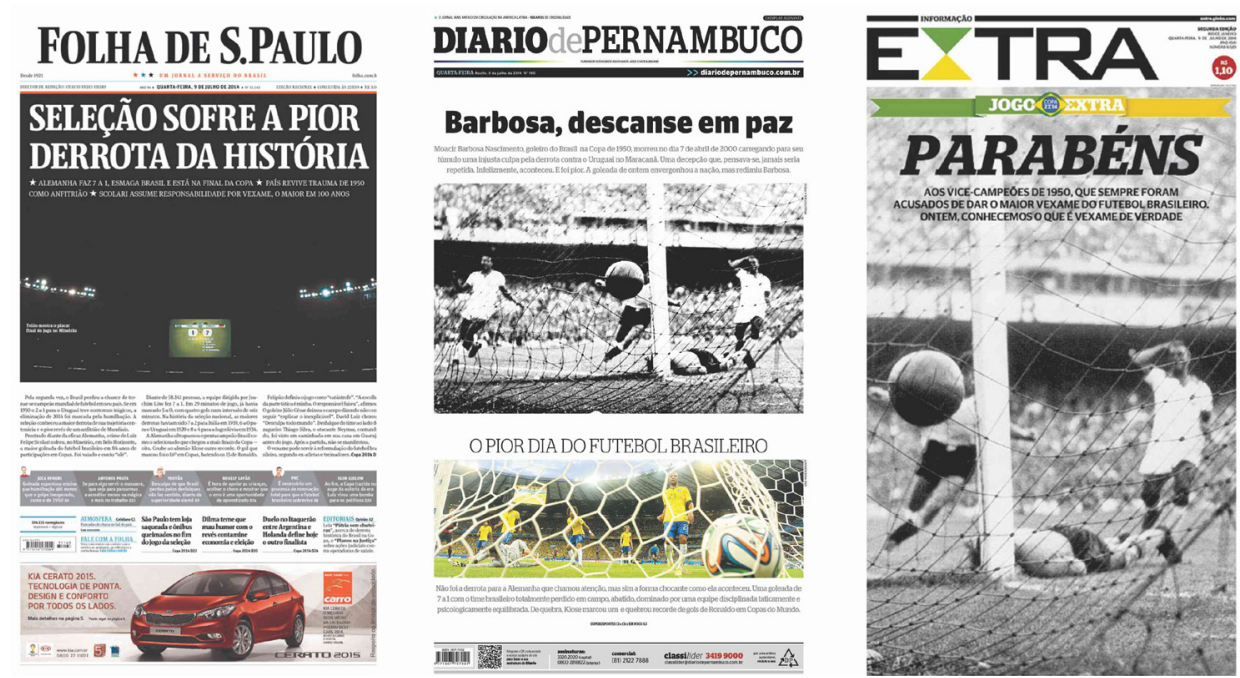

A capa do jornal Diário de Pernambuco traz os seguintes dizeres:

Barbosa, descanse em paz. Moacir Barbosa Nascimento, goleiro do Brasil na Copa de
1950, morreu no dia 7 de abril de 2000 carregando para seu túmulo uma injusta culpa
pela derrota contra o Uruguai no Maracaná. Uma decepçáo que, pensava-se, jamais
seria repetida. Infelizmente, aconteceu. E foi pior. A goleada de ontem envergonhou a
nação, mas redimiu Barbosa (DIÁRIO DE PERNAMBUCO, 2014, p. X).

Sabe-se que um dos sentidos do termo redimir é a existência primeiro de algo que carrega certa culpa e só depois surge algo que recupera a imagem ou diminui a culpabilidade. Conforme Carvalho (2012, p.173), "Narramos para criar mundos idealizados, nas fabulaçóes que constroem mundos imaginários, sugerem realidades fantásticas, mas também para buscarmos explicaçóes racionais, para entendermos nosso passado". No universo da narrativa, Barbosa só após 2014 é o goleiro vice-campeáo da Copa do Mundo de 1950 e não o goleiro que cometeu a falha que custou o título da competição. O enunciador, com efeito desenvolve um efeito de autoridade, pois acaba de libertar o goleiro de seu pesadelo.

Nota-se uma transformação de um estado em outro, como diz Fiorin (2009), quando o enunciador fala da redenção de Barbosa em virtude do surgimento de uma nova vergonha futebolística para a nação. Barbosa passa de sujeito culpado a não mais o responsável pela maior derrota futebolística nacional. Desse modo, o enunciador coloca Barbosa em conjunção com a redenção e em disjunção com tal responsabilidade. Não se tira do goleiro a culpa pela derrota de 1950, ela provavelmente continuará. O que se tem é uma amenização, pelo o que é possível constatar na narrativa midiática. A goleada de $7 x 1$ entra em conjunção com a vergonha e com a humilhação. Ao mesmo tempo, permite certa disjunção entre a seleção de 1950 e o status de vexame supremo.

As transformaçóes de estado podem ser vistas também nos enunciados presentes na capa do Jornal Extra: "Parabéns aos vice-campeóes de 1950, que sempre foram acusados de dar o maior vexame do futebol brasileiro. Ontem conhecemos o que é vexame de verdade". (EXTRA, 2014, p. ) O vexame de 2014 sobrepóem-se ao de 1950. Da mesma forma que na capa do Diário de Pernambuco, ocorre a diminuição de um acontecimento pela ocorrência de 
um novo. Outra mudança de estado situa-se no "parabéns" que é dado aos jogadores de 1950. Ocorre um reconhecimento, 64 anos depois, da importância daquele vice-campeonato, conquista mais importante da seleçáo nacional até aquela data. Os vice-campeóes, de sacrificados historicamente, passam a receber o reconhecimento do enunciador.

Na capa do Jornal Folha de São Paulo lê-se: "Seleção sofre a pior derrota da história: [...] País revive trauma de 1950 como anfitrião [...]". (FOLHA DE SÃO PAULO, 2014, p. ) No primeiro enunciado, realiza-se uma conjunção da seleção de 2014 com a pior derrota da história que, implicitamente, remete a uma disjunção da seleção de 1950 com a referida qualificação. Na sequência, o Maracanaço é abordado diretamente quando o enunciador faz referência à dimensão traumática dos dois acontecimentos.

Afirma-se que o 7x1, ao menos na narrativa midiática, desperta outros sentidos em relação ao acontecimento de 1950. Segundo Ricoeur (1997, p.193), "torna-se porosa a fronteira que separa o passado histórico da memória individual". Passados 64 anos, a derrota para o Uruguai continua ativa na memória esportiva nacional, enquanto a derrota para a Alemanha e também as narrativas midiáticas invadem os poros lançando e instaurando novos sentidos para o já vivido. Os pequenos enunciados ressaltados, através de constante reiteração, tornam-se configuradores de uma outra imagem sobre o Maracanaço. A ferida de 1950 continuava aberta e incicatrizável até o $7 x 1$. Mesmo deixando suas marcas, ela se encontra cicatrizada ao menos nos fragmentos narrativos analisados. Em resumo, o Maracanaço deixa de ser a pior derrota da história do futebol nacional, exime-se da culpa aquele que era considerado o principal vilão e, 64 anos depois, aquela seleção adquire reconhecimento pelo feito alcançado, ser vice-campeã. As narrativas alimentam uma tensão de que se fosse possível voltar-se-ia no passado para mudá-lo. Antes da realização da Copa do Mundo trabalhava-se a questão de que 2014 seria a oportunidade de redimir a seleção de 1950. Após a derrota de 2014 foi praticamente unânime nos jornais a narrativa da redenção de 1950. Entretanto, a redenção não ocorreu com uma vitória na final do torneio no estádio do Maracanã, mas com uma derrota pior que aquela.

Não se pode desconsiderar também que a recuperação do Maracanaço e de seus aspectos traumáticos, como a constituição de vilóes, resulta de uma estratégia editorial que tem potencial de atração do leitor. No âmbito da questão, pode-se lançar uma crítica a tal comportamento, visto como oportunista pois as opinióes mudam em virtude de um resultado. Sustentou-se uma imagem por vários anos sobre 1950 . O resultado de $7 x 1$ provoca um abalo e a mídia esquece as abordagens realizadas anteriormente que a transformaram no principal agente de construção da imagem dos derrotados de 1950. Destaca-se que há um grande trabalho midiático realizado ao longo dos quatro anos que separam as ediçóes da Copa do Mundo. A derrota frustrou o sonho não só dos torcedores mas também da imprensa e não só de apagar o fantasma de 1950, mas de ver o Brasil disputar novamente, em uma Copa sediada em seu país, uma final do estádio do Maracanã. 
Retomando Ricoeur (1994), pensa-se que o Maracanaço faz parte de um mundo pré-figurado (mimese I) em relação ao 7x1, que também passou por um processo de configuração (mimese II) e refiguração (mimese III) através de narrativas. A compreensão narrativa possibilita o que o autor chama de retorno do acontecimento. Capas como a do Diário de Pernambuco e do Jornal Extra releem 1950 com o olhar do 7x1 e surgem novas configuraçôes, que já não são as mesmas daquelas realizadas antes da derrota de 2014 pois, na produçáo do novo que será colocado à prova num ato de leitura (refiguração), faz-se presente o que já estava consolidado sobre o Maracanaço. A mesma imagem utilizada pelos jornais com a intenção de mostrar uma redenção é a mesma que muitas vezes serviu para incriminar Barbosa, ou seja, instaura-se um sentido a mais para ela.

O acontecimento retorna com uma nova significação, especialmente pelos viés midiático. Sobre a interpretação de 1950 passa a pesar a derrota de 2014. Ocorre uma ressignificação e a mídia esportiva assume um papel inicial de agente de refiguraçáo. Em meio a leitura, pode-se dizer que revive a cobertura esportiva realizada ao longo dos anos, geralmente pautada pelos aspectos traumáticos da derrota. As desculpas a Barbosa e o parabéns pelo vice-campeonato surgem pelo fato do oposto já estar dito. Por isso, ao propor a configuração do acontecimento de 2014, quando retoma o papel de mimese II, exime os jogadores de 1950 da culpa pelo maior vexame da história do futebol nacional. Após a releitura, surgem novas configuraçôes sujeitas a novas interpretaçóes pelos sujeitos leitores. Mimese II, portanto, possui uma "função de mediação" ao estabelecer o agenciamento de fatos e acontecimentos com o momento futuro de leitura (RICOEUR, 1994, p.102). Já o leitor, responsável pela mimese III, é o "operador por excelência” do processo. Eis a razão de pensarmos que os enunciadores, em relação aos acontecimentos aqui analisados, transitam entre os dois papeis. O ciclo, no entanto, não se fecha completamente, pois a culpa pelo maior vexame é repassada a outros jogadores, aos do 7x1, em que o efeito poderá ser monitorado ao longo dos próximos anos.

Para Ricoeur (1994, p.103), "um acontecimento dever ser mais que uma ocorrência singular. Ele recebe sua definição de sua contribuição para o desenvolvimento da intriga". Com efeito, a derrota para a Alemanha encaixa-se na derrota para o Uruguai e provoca novas interpretaçóes. O 7x1 não é um acontecimento isolado, pois aparece inserido em uma das narrativas futebolísticas que versam sobre a seleção brasileira e alguns de seus traumas. Nem as cinco conquistas posteriores (1958, 1962, 1970, 1994 e 2002) foram capazes de apagar o jogo de 1950. Eis uma das razóes que faz uma tragédia futebolística antiga ser mencionada mesmo que a recente pode ser explorada exaustivamente.

Um acontecimento pode ser atualizado por outro ou pela narrativa. Como diz Ricoeur (1994, p.118): "Seguir uma história é atualizá-la na leitura”. Pode-se dizer que as instâncias midiáticas monitoram e sustentam por anos uma narrativa sobre algo e podem atualizá-la através das leituras que fazem e de novos sentidos que são apresentadas aos demais leitores. Além 
disso, cada leitura é uma nova leitura que carrega a interpretação gerada anteriormente. Ler sobre 1950 antes de 2014 é diferente do que lê-lo após o resultado de $7 \mathrm{x} 1$. A história continua viva, continua sendo narrada e continua a propor novas leituras, pois os sentidos são passíveis de mudança em virtude da ocorrência de novos acontecimentos.

O sofrimento pela derrota está representado em capas que optaram por explorar a melancolia através de imagens de choro e da incredulidade de jogadores e torcedores. Toma-se como exemplo apenas três capas de jornais, mas várias foram aquelas que classificaram a derrota de 2014 como o maior vexame do futebol brasileiro. Com efeito, desloca-se o sentido de maior vexame para outro acontecimento, ao mesmo tempo em que um acontecimento anterior é atualizado em termos de compreensão. Reconfigura-se assim, um acontecimento passados 64 anos. As significaçóes inserem-se no acontecimento, adaptam-se a ele, ao mesmo tempo em que o adapta a corrente de outros acontecimentos. $\mathrm{O}$ tratamento midiático é uma das formas de constituição de uma segunda vida do acontecimento.

Pensa-se que a narrativa seja uma forma de mediação, mesmo a fragmentada que se encontra nas capas, que dá ao Maracanaço e à derrota de 2014 uma dinamicidade em termos de sentidos e ao mesmo tempo certa flexibilidade, além de pôr em ligação dois tempos históricos, duas interpretaçôes e promover o agenciamento de dois acontecimentos. O modo como a narrativa atua revela conclusóes sobre como a história e os acontecimentos foram tecidos ao longo do tempo. O Maracanaço não deixa de ser um acontecimento fundador, bem como a Copa de 1950. Ao ser realizada no Brasil, fez o país aparecer para o mundo do futebol e começar a sedimentar a cultura futebolística nacional.

A negociação de sentidos acerca de um acontecimento ganha novos capítulos, tanto pela ocorrência de um novo acontecimento quanto pelo fazer midiático, que busca interpretá-lo e estabelecer conexôes com outros. Trata-se de um processo natural um novo acontecimento dentro de uma mesma temática lançar sentidos sobre acontecimentos anteriores. Através do 7x1 surgem novas interpretaçôes sobre o Maracanaço. Um personagem como Barbosa, de grande viláo passa a ser dono de um feito relativamente importante. No entanto, pelo fato do reconhecimento vir somente após o resultado, afirma-se que os dizeres utilizados enaltecendo os jogadores de 1950 servem mais para realçar os contornos vexatórios do $7 \mathrm{x} 1$ do que para fazer a reverência. Naquele acontecimento havia a brecha de um outro acontecimento vir e atualizá-lo ou fazê-lo retornar, possibilitando a intervenção de um novo olhar, ou seja, a intriga recebe novos pontos em sua tessitura. As capas analisadas lançam novos sentidos sobre o acontecimento primeiro através de um processo de retorno, de releitura que gera uma nova configuração posta à disposição do leitor para um novo ato de refiguração. Entende-se que as capas sobre o 7x1, que mencionam o Maracanaço, procuram modificar a experiência do passado. Aliás, todas elas modificam a experiência do próprio $7 \mathrm{x} 1$ que, certamente, não é a mesma daquela vivida no momento em que ocorreu o resultado. 


\section{Considerações finais}

A narrativa midiática, na contemporaneidade, em seus diversos formatos, é um modo de apreensão e configuração dos acontecimentos e continua a ser um modo de configuraçáo de sentidos acerca do mundo, nos diversos âmbitos da sociedade, entre eles o esporte. A constante atualização de mitos acerca de competições e feitos esportivos históricos, a configuração de heróis e vilóes e demais personagens, o espírito de nacionalismo, a exploração das performances e da carreira dos atletas, do sucesso e o insucesso, são alguns exemplos. Todos são exemplos de narrativas que constituem e são constituídas na esfera midiática, mas que, ao mesmo tempo, estão além e dependem para sua apreensão mais ampla do contexto que a envolve e dos atores sociais envolvidos. Pode-se dizer, consequentemente, que a narrativa que se analisa não está dada na superficialidade, não está apenas no corpus, mas está também, certamente, nos valores, no simbólico, na cultura, no modo como é explicada e compreendida.

Toda narrativa possibilita uma interação, num processo de agenciamento com outras narrativas, de agenciamento entre os sujeitos que resulta numa produção constante de conhecimento e de novas experiências. A narrativa é algo que se alastra, algo que se movimenta, algo que se desdobra em âmbito social, cultural, histórico, simbólico e discursivo. Afirma-se que ela articula acontecimentos e tenta dar inteligibilidade a eles instaurando e desenvolvendo modos de apreensão do mundo. Acontecimentos que estão sempre dotados de uma capacidade de revelação e de certo poder hermenêutico que a própria narrativa também carrega. Em relação ao $7 x 1$, por exemplo, revela-se uma sucessão de fatos, fenômenos e nuances, por vezes silenciados, que culminaram na pior derrota da história da seleção brasileira de futebol. Finalizando, o trabalho da narrativa em relação aos acontecimentos, como nos dizem os autores utilizados ao longo do estudo, é um trabalho de confrontação com o mundo, de confrontaçáo dos sujeitos com o mundo e de suas visôes acerca do mundo. A embrionária junção entre as visadas pragmatista e hermenêutica aqui realizada possibilitou captar e promover uma compreensão mais ampla de um acontecimento e de seu potencial narrativo. 


\section{Referências bibliográficas}

BARBOSA, descanse em paz. Diário de Pernambuco. Recife, 9 jul. 2014. CARVALHO, Carlos Alberto de. Entendendo as narrativas jornalísticas a partir da tríplice mimese proposta por Paul Ricoeur. Matrizes. São Paulo Ano 6, n.1, p.169-187, jul-dez 2012.

CARVALHO, Carlos Alberto de; LAGE. Leandro. Narrativa como mediação fundamental da experiência dos acontecimentos: a mise en intrigue midiática. Contemporânea. Salvador. vol. 10, n.1, p.207-222, jan-abril 2012.

CHARAUDEAU, Patrick. Discurso das mídias. São Paulo: Contexto, 2006.

FRANÇA. Vera. O acontecimento para além do acontecimento: uma ferramenta heurística. In: FRANÇA, V. R. V.; OLIVEIRA, Luciana de. (Orgs.). Acontecimento: reverberaçôes. Belo Horizonte: Autêntica, 2012.

FIORIN, José Luiz. Elementos de análise do discurso. São Paulo: Contexto, 2009.

LEAL, Bruno Souza. O jornalismo à luz das narrativas: deslocamentos. In: LEAL, Bruno Souza; CARVALHO, Carlos Alberto de (Orgs.). Narrativas e poéticas midiáticas: estudos e perspectivas. São Paulo: Intermeios, 2013.

PARABÉNS. Extra. Rio de Janeiro, 9 jul. 2014.

QUÉRÉ, Louis. Entre facto e sentido: a dualidade do acontecimento. Trajectos: Revista de Comunicação, Cultura e Educação, n.6, p.59-76, 2005. A dupla vida do acontecimento: por um realismo pragmatista. In: FRANÇA, Vera; OLIVEIRA, Luciana de. (Orgs.). Acontecimento: reverberaçóes. Belo Horizonte: Autêntica, 2012.

RESENDE, Fernando. O jornalismo e suas narrativas: as brechas do discurso e as possibilidades do encontro. Galáxia, São Paulo, n.18, p.31-48, dez. 2009.

RICOEUR, Paul. Tempo e narrativa, Tomo I. Campinas - SP: Papirus, 1994.

Papirus, 1997.

. Tempo e narrativa, Tomo III. Campinas - SP:

SELEÇÃO sofre a pior derrota da história. Folha de São Paulo. São Paulo, 9 jul. 2014. 